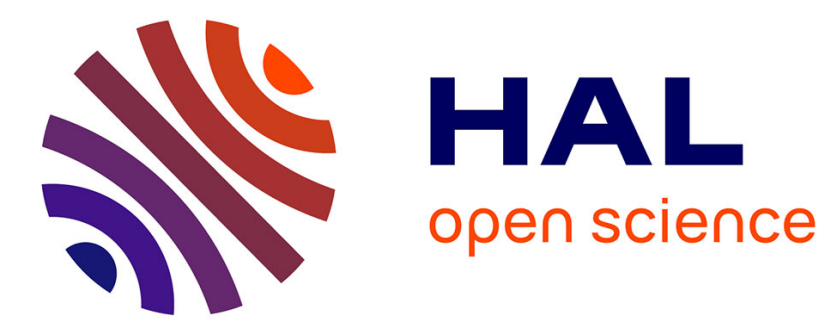

\title{
Lessons from the periphery: psychiatry in Saskatchewan, Canada, 1944-68
}

\author{
John A. Mills
}

\section{To cite this version:}

John A. Mills. Lessons from the periphery: psychiatry in Saskatchewan, Canada, 1944-68. History of Psychiatry, 2007, 18 (2), pp.179-201. 10.1177/0957154X06073011 . hal-00570871

\section{HAL Id: hal-00570871 \\ https://hal.science/hal-00570871}

Submitted on 1 Mar 2011

HAL is a multi-disciplinary open access archive for the deposit and dissemination of scientific research documents, whether they are published or not. The documents may come from teaching and research institutions in France or abroad, or from public or private research centers.
L'archive ouverte pluridisciplinaire HAL, est destinée au dépôt et à la diffusion de documents scientifiques de niveau recherche, publiés ou non, émanant des établissements d'enseignement et de recherche français ou étrangers, des laboratoires publics ou privés. 


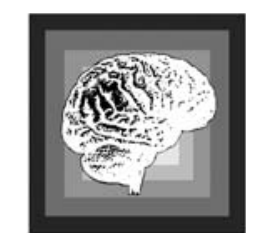

\title{
Lessons from the periphery: psychiatry in Saskatchewan, Canada, $1944-68$
}

\author{
JOHN A. MILLS* \\ University of Saskatchewan
}

\begin{abstract}
The government of the Saskatchewan Co-Operative Commonwealth Federation, when elected in 1944, established programmes for the statefunded care of all those suffering from mental illness. It enacted legislation covering the care and treatment of the mentally ill and created a division of the Department of Public Health, the Psychiatric Services Branch (PSB), which both recruited and trained psychiatric staff, meeting the need for nonmedical staff by creating a programme for the training of psychiatric nurses in Saskatchewan. The PSB devised the Saskatchewan Plan for the delivery of rural services, centred on small mental hospitals of a revolutionary design. Even though never fully instantiated, the Plan commanded worldwide attention. Saskatchewan was also remarkable for its research programmes, covering almost all aspects of psychiatry.
\end{abstract}

Keywords: adrenochrome hypothesis; Canada; community psychiatry; deinstitutionalization; Hoffer; LSD; Osmond; Saskatchewan Plan

\section{Introduction}

It is a set of truisms to say that community psychiatry, the profession's 'third revolution', was possible because of the widespread introduction of welfare states following World War II, that the broadening of psychiatry's professional base, especially because of the growing influence of psychoanalysis, was a contributing factor, and that the profession's increasing self-confidence resulting from the introduction of various physical therapies (even if most proved to be ultimately ineffective) played a role. Above all, during World War II

\footnotetext{
* Address for correspondence: 5275, Seawright Road, Hornby Island, British Columbia, V0R 1Z0, Canada. Email: millsj@telus.net
} 
not only did British and American psychiatrists develop effective short-term treatments for battlefield neurosis but some of them saw the implications for peace-time psychiatry. It is, however, surprising that, in North America, those factors should have been instantiated for the first time in the Canadian province of Saskatchewan.

Saskatchewan is remote from Canada's metropolitan centres; its capital, Regina, is $571 \mathrm{~km}$ from the nearest large city, Winnipeg, and $4035 \mathrm{~km}$ from Ottawa. Until the 1970s its population was mainly rural and it had no large cities. Moreover, the province, whose principal economic activity had been the growth of wheat and other cereal crops, had been economically devastated by the Depression and by a severe drought in the 1930s. World War II restored Saskatchewan's economy, and the province was set on an upward course with the election of North America's first effective socialist government in 1944 .

The new premier, Thomas ('Tommy') Clement Douglas (1904-86) was one of Canada's most brilliant and effective politicians (for biographies of Douglas, see: McLeod and McLeod, 1987; Shackleton, 1975; Stewart, 2003). He embodied the highest version of the ideology driving the form of socialism unique to western North America, which the political sociologist Seymour Martin Lipset (1968) has called 'agrarian socialism'. Douglas was, however, much more than an idealist in that he was a superb proponent of political craft. He was also one of Canada's great administrators with, for example, a complete command of the principles and practices underlying fiscal policies. ${ }^{1}$

The Saskatchewan Co-Operative Commonwealth Federation (CCF) came to power with a prior commitment to create some form of medicare, but had assumed no obligations to those suffering from mental illness. Douglas, who had taken the unusual step of combining the offices of Premier and Minister of Public Health, was the ultimate architect of the Saskatchewan CCF's programme of mental health (see Hall, 1979). ${ }^{2}$ Although we can never know precisely what motivated Douglas to make a mental health programme a priority for the province, it is probable that his desire to improve the lot of the mentally ill can be traced back to his research, as a young man, into eugenics. In 1933 he had completed a Master's thesis in which he had studied the relative reproductive rates of a sample of women committed to the Saskatchewan Hospital Weyburn and of a group of 'normal women'. $\mathrm{He}$ found that the inmates had a higher rate of reproduction than the normal sample and drew the conclusions usual for the time, namely, that restrictions such as sterilization should be placed on the reproductive capacities of those suffering from severe forms of mental illness, from mental deficiency or from forms of social pathology such as alcoholism (McLaren, 1990: 7-9, 166-7).

By the time he acquired political power, Douglas's ideological fervour had softened and become transmuted into a passionately humane concern for all those suffering from illness, whether physical or mental. ${ }^{3}$ The transformation 
of coercive or restrictive attitudes towards mental illness into sympathetic concern was given concrete manifestation in a set of letters he wrote to concerned members of the public repudiating the use of sterilization. ${ }^{4}$ Very soon after entering office, Douglas and his government began to set the stage for the introduction of state-funded health programmes. In 1944 Douglas invited the American medical historian Dr Henry Sigerist to tour the province, to write a report describing the current state of the province's health programmes, and to make recommendations for improving them (for a summary of those recommendations, see Dickinson, 1989: 77-82). The government began to enact Sigerist's recommendations with commendable dispatch. In the case of physical health the government was, essentially, faced with the task of rationalizing and universalizing a set of private health insurance schemes, some of which provided comprehensive coverage for their members. ${ }^{5}$

As Sigerist had recommended, the government decided that services to the mentally ill should be offered free of charge. It therefore had to rewrite the Act dealing with mental illness (the Mental Hygiene Act of 1936). On 8 April 1950 a new version of the Act granting such a right passed into law. ${ }^{6}$ The costs of caring for and treating all those diagnosed as suffering from mental illness after 1 January 1946 were to be borne by the government. The control of admission to mental institutions constituted the second major difference between the new and the old Acts; in the new one, admission was controlled almost entirely by the medical profession. A section on alcoholism and addiction constituted the third major difference between the old and the new Acts. In addition to committing itself to bearing the financial costs of mental illness, the government broadened the scope of application of the Act by including a section on voluntary patients, provided that such people arrived at a mental institution with a letter from a physician recommending treatment.

Douglas and his government knew that, in order to ensure adequate health care, they had to create a fully fledged College of Medicine which, in turn, would have to have a close association with a university hospital. They therefore provided the required funding to the University of Saskatchewan, ${ }^{7}$ enabling it to open the College in 1952. The College's Department of Psychiatry started operating on 1 July 1955.

Building a mental health programme presented the government with a formidable task. The facilities and services available comprised two overcrowded mental institutions (at Weyburn and North Battleford) and a mental health clinic. The medical staff was below complement and often lacked psychiatric training, while the attendants in the mental hospitals were inadequately trained and had poor morale. ${ }^{8}$ Consequently, even before expanding and improving the services available to those suffering from mental illness, especially to those who did not require institutionalization, the government had to deal with the severe overcrowding and poor physical conditions in these two mental hospitals. In 1946 they had a total patient 
population of 4249 and were $100 \%$ overcrowded relative to a 1930 baseline (Hall, 1979, VI: 9).

Douglas did not flinch and on 1 November 1946 he appointed Donald Griffith ('Griff') McKerracher (1909-70) as the province's Commissioner of Mental Health. This was an inspired appointment. Even if McKerracher was clinically naive, appearing to believe that mental illness would succumb to a mixture of care, sympathy, concern and trust, that naivety was more than counterbalanced by the depth and sincerity of his concern for the plight of the mentally ill. Because he was a man of immense charm, he easily persuaded others to share his concerns. ${ }^{9}$

\section{The creation of the Saskatchewan Psychiatric Services Branch}

On 1 April 1950 the Government of Saskatchewan provided McKerracher with the instrument he needed to build a comprehensive programme of community psychiatry by forming a division of the Department of Public Health, the Psychiatric Services Branch (PSB), with McKerracher as the first director. In that role, five achievements stand to McKerracher's credit (Hall, 1979, VI: 15-19, 20-2):

1. He improved the operation of Saskatchewan's mental hospitals. He increased the medical staffs, removed the worst wards, abolished the use of isolation and mechanical restraints as means of controlling patients, and introduced pilot programmes such as trial leaves and the relaxation of criteria determining the release of patients.

2. He developed a system of permanent outpatient clinics, unique in North America at the time. The first opened in the Munroe Wing of the Regina General Hospital in November 1947. By the end of 1947, clinics were operating at Weyburn, North Battleford and Moose Jaw. By 1951 the MacNeill Clinic in Saskatoon was operating full-time and there were part-time clinics at Assiniboia, Swift Current, Prince Albert and Yorkton.

3. He created a programme for the training of psychiatric nurses in the province, thereby laying the essential foundation for a successful programme of community psychiatry. ${ }^{10}$

4. He started the first fully funded province-wide psychiatric research programme in psychiatry in any Canadian province in July 1950.

5. He began to engage the public in mental health issues. He started a citizens' committee in 1949, with representatives from the clergy, labour, education, the municipalities and women's organizations. The first task of the branches of the committee was to visit mental institutions. McKerracher also established an early liaison with a highly influential and effective organization, the Canadian Mental Health Association (for a history of the CMHA, see Griffin, 1989). The CMHA's General Director, Clarence Meredith Hincks (1885-1964) had already 
approached the then Federal Minister of Health and Welfare, Paul Martin, $\mathrm{Sr}$, in order to obtain funding for the initiation of provincial branches of the national organization. ${ }^{11}$ Martin suggested starting with a pilot project. Saskatchewan was selected because of its innovative mental health policies. A senior member of the CMHA, Professor Samuel Laycock, was asked to establish a provincial organization. $\mathrm{He}$ collaborated with McKerracher in creating programmes to improve the lot of those suffering from mental illness.

As a result of the CMHA's decisive role, Saskatchewan was exceptional not only in being the first Canadian province to introduce a comprehensive programme for the humane treatment of mental illness, it was also exceptional in that the CMHA (Sask) acted as a powerful advocate for those suffering from mental illness: in attempting to ensure that mental health services were improved, in funding research into mental illness, in educating the public about the nature of mental illness, and, to some extent, in providing mental health services. CMHA (Sask) had close links with both the government (Douglas and all his cabinet were members) and with the PSB (all the senior psychiatrists were members). Moreover, at the height of its influence in the late 1950s CMHA (Sask) had 15 branches and a membership of 50,000, and its leading figures were energetic, articulate and committed.

In principle, it should have enhanced levels of mental health care in the province, especially through its public education programmes. Certainly, McKerracher used the CMHA (Sask) to lay the foundations for programmes to support released institutionalized patients. He approached Marjorie Cooper, later to become a CCF Member of the Legislative Assembly, who persuaded Agnes Davidson of the Regina branch of the CHHA (Sask) to institute a system of volunteer visitors at Weyburn (the first visit was in May 1952). Once the service had been successfully established, it was extended to North Battleford. By 1960 the Regina group comprised 800 regular visitors. (Hall, 1979, VI: 9) ${ }^{12}$

Although McKerracher toyed with a plan to build a third large mental hospital in Saskatoon, a prominent feature of his career was his commitment to community psychiatry, despite the unpropitious situation facing him when he arrived in Saskatchewan. ${ }^{13}$ However, he rapidly regained his confidence in the ultimate value of community psychiatry. But his most striking attributes were his self-confidence and his faith in his powers to persuade others of the value of his programmes and policies. That self-confidence set an enduring stamp on Saskatchewan psychiatry for roughly twenty years. For example, in order to meet his staffing requirements, McKerracher rapidly began to train psychiatrists himself, a bold move because, when he started his programme, the University of Saskatchewan's medical school was at best embryonic. Even so, McKerracher's was the only in-province training programme in 
psychiatry to be certified by the Royal College of Physicians and Surgeons. Two of the psychiatrists he trained, Dr Abram Hoffer (b. 1917) and Dr John Cumming (b. 1917), became prominent in the profession, while others such Dr Nick Chwelos had successful careers. In addition, instead of following the Canadian tradition of building on an affiliation with the USA, McKerracher persuaded psychiatrists from Britain and some other countries to work in Saskatchewan. On the whole, those who joined the PSB did so because they were committed to the ideals of community psychiatry and so they established innovative programmes which in turn attracted other talented psychiatrists to work in the province. Overall, despite recurrent recruiting problems, staffing levels remained adequate. For example, in 1958, 1959 and 1960 the PSB's medical staff numbered between 55 and 57 (20 of whom were psychiatrists), while the number of nursing and other patient care staff remained constant at 1156 (Final Report ..., 1962: 23).

\section{The Saskatchewan Plan}

On 1 July 1955 McKerracher took up the post of Head of the Department of Psychiatry at the University of Saskatchewan. He was succeeded as Director of the PSB by Frederick Samuel ('Sam') Lawson (1903-70). Lawson was one of North America's most prominent community psychiatrists, and his is the name most strongly associated with the Saskatchewan Plan, a means for delivering psychiatric services to a dispersed rural population.

The Plan first took shape in some informal discussions between McKerracher, Lawson and the Medical Superintendent of Weyburn, Humphry Osmond (Kahan, 1965: 82). In its most comprehensive version, as developed by Lawson and some of the head office staff of the PSB, the Plan called for the division of the province into two urban (Regina and Saskatoon) and six rural mental health districts, each serving a mean population of about 73,000 and of such a size that no patient would have lived more than $130 \mathrm{~km}$ from a mental hospital (Lawson, 1957, 1958, 1967; Lawson and Izumi, 1965; McMillan, 1957; Rands, 1960). Outside the two largest urban centres those services were to have been centred on small purpose-built mental hospitals (in the first version of the plan, the size of the hospitals would have varied from 238 to 448 beds). Besides providing institutional care and treatment, the hospitals were to have served as the centres for travelling clinics staffed by psychiatrists, social workers and psychiatric nurses, so that most of each region's treatment would have been delivered within the community rather than at its hospital.

The start of Lawson's tenure as the Director of the PSB coincided with the presentation to the government of a set of highly disturbing reports about the situation at the Saskatchewan Hospital, Weyburn. ${ }^{14}$ The hospital was appallingly unhygienic, standards of care, even at a very basic physical level, were disgraceful, while all the menial tasks were carried out by a group of aging, 
largely male patients - in fact, their lives were hardly different from those of their counterparts in the large mental hospitals of the mid-nineteenth to mid-twentieth centuries. The Deputy Minister of Public Health, Dr F. Burns Roth, asked Lawson to generate policies for dealing with the situation. Lawson responded by producing an outline of the Saskatchewan Plan and presenting it as his only option. ${ }^{15} \mathrm{Had}$ the government followed Lawson's recommendations it would have used up almost all funds available for new capital expenditure and almost all the expected budgetary increments for a decade (Hall, 1979, IV: 40). Since Saskatchewan's per capita expenditures on mental patients were already the highest in Canada, the government could not accept Lawson's recommendations. His response was to elicit support from the CMHA (Sask), which launched itself on an extensive lobbying campaign. To make matters worse, Lawson gave a speech to a CMHA meeting in which he criticized the government for what he saw as inhumane treatment of those suffering from mental illness. ${ }^{16}$ Privately, Douglas was furious, but he had to swallow his rage because, as Roth pointed out to him, it would be well-nigh impossible to find a replacement for Lawson.

Ultimately, and begrudgingly, the government did build one regional psychiatric centre at Yorkton. ${ }^{17}$ In addition, because of the considerable freedom of action granted to the PSB and its senior staff, attenuated versions of the Saskatchewan Plan were put into effect. In 1963-66 the Plan reached its apogee in the work of Hugh Lafave and Frederic Grunberg, respectively Medical Superintendent and Clinical Director of the Saskatchewan Hospital, Weyburn. Lafave and Grunberg reduced the Hospital's patient population from 1519 to 421 in those three years. This $72 \%$ reduction was the highest rate of de-institutionalization ever recorded in any mental institution anywhere in the world (Hall, 1979, VI: 40). Moreover, the patients were not merely discharged but were placed in approved homes under the overall supervision of psychiatric nurses, so that Sigerist's and McKerracher's policies did find their ultimate fulfilment.

\section{Psychiatric research in Saskatchewan}

Innovative work in community psychiatry in a remote Canadian province is surprising enough. Even more surprisingly, Saskatchewan instituted Canada's first provincially funded psychiatric research programme. To add yet more surprises, Saskatchewan researchers were prodigiously productive and much of the research was of high quality. ${ }^{18}$ Indeed, for a short time Saskatchewan was one of the world's leading centres for research into the neurochemical origins of schizophrenia.

Humphry Fortescue Osmond (1917-2004) had realized that the observed effects of lysergic acid diethlyamine-25 (LSD), which at that time were taken to be its psychotomimetic attributes, provided a possible avenue towards the understanding of the neurochemical origins of schizophrenia. 
He and the biochemist John Smythies had suggested that some naturally occurring analogue of LSD might be the psychopharmacologic agent causing schizophrenic symptoms (Osmond and Smythies, 1952). Osmond and Smythies were, however, unable to secure research funding, whereas McKerracher did promise them funding and in 1951 appointed Osmond to a post at Weyburn. When he arrived in Saskatchewan, Osmond met Hoffer, who besides having an MD had a PhD in biochemistry; his thesis subject had been the B vitamins. As a result of Hoffer's and Osmond's collaboration with a University of Saskatchewan biochemist, Duncan Hutcheon, they began to explore the metabolic pathways of adrenalin (epinephrine) because of its chemical similarities to LSD. Hutcheon suggested that a breakdown product of adrenalin, adrenochrome (or the chemically similar adrenolutin), could be the active psychogenic agent. Heroically, Hoffer and Osmond injected themselves, their wives and some of their research associates with adrenochrome and convinced themselves that it had psychotomimetic qualities.

The Hoffer-Osmond adrenochrome theory is a version of what is known as the transmethlyation hypothesis. In order to understand the hypothesis one has to know, first, that adrenalin (epinephrine) is a catecholamine and that all catecholamines are monamines, that is, they have only one amine $\left(\mathrm{NH}_{2}\right)$ group. Second, all catecholamines have the same nucleus (catechol), which consists of a benzene ring with two hydroxy side-chains; the nucleus also provides a site for the addition of the amine side-chain. Third, catecholamines differ from one another in the presence or absence of methyl $\left(\mathrm{CH}_{4}\right)$ groups, either at some point on the benzene ring or within the amine side-chain. Furthermore, the methyl group can either be attached to an oxygen molecule (O-methylation) or to a nitrogen molecule (N-methylation). Fourth, and most crucially, both the addition and subtraction of methyl groups and the site of the bonding alters a catecholamine's biochemical and hence its psychopharmacological properties (Healy, 2002: 182-95).

The adrenochrome theory states that adrenochrome, one of adrenaline's breakdown products, is the psychogenic agent in schizophrenia. Supposedly, in the schizophrenic brain, but not in the normal brain, adrenochrome breaks down relatively slowly and its accumulation causes schizophrenic symptoms (Hoffer and Osmond, 1959, 1960, 1967: 225-6; Hoffer, Osmond and Smythies, 1954; Osmond and Hoffer, 1961/2, 1966). Hoffer went even further by stating that massive doses of nicotinic acid could counteract the effects of over-secretion of adrenochrome by reducing the numbers of potential methyl donors in the brain and thereby reducing the amounts of adrenalin (and hence of adrenochrome) produced. Therefore, Hoffer and Osmond had proposed not just a theory for the origins of schizophrenia but a chemically-based therapy. It should also be noted that Hoffer believed, and continues to believe, that schizophrenia could be cured and not merely 
managed psychopharmacologically. Almost as soon as the University Hospital opened in Saskatoon, Hoffer established a laboratory there and conducted a wide-ranging programme of research. Among his other achievements, he carried out psychiatry's first double-blind test into the efficacy of nicotinic acid therapy and reported that it was effective.

Hoffer and Osmond's adrenochrome theory was the world's first theoretically based and empirically testable theory of the biological origins of schizophrenia, and therefore it attracted substantial research funding. ${ }^{19}$ David Healy (2002: 185-6) commented:

... Hoffer, Osmond, and Smythies ... produced a coherent theory of schizophrenia, along with a treatment that appeared to produce some benefits and certainly provoked considerable interest. In addition, their ideas tapped straight into an increasing public awareness of the hallucinogens, which as a group were referred to as the psychedelic drugs, a term coined by Osmond. The heady buzz that resulted made Saskatchewan in the 1950s one of the focal points of the psychiatric universe.

However, eventually Hoffer's claims could not be substantiated and the theory fell into disrepute. ${ }^{20}$ Crucially, no laboratory other than Hoffer's ever detected adrenochrome in blood samples. A team from the American National Institute of Mental Health visited the Saskatoon laboratory and concluded that Hoffer's data were an artefact of ascorbic acid in his blood samples. Because Hoffer refused to retract his assertions, organizers of international meetings ceased to invite him or his researchers to present papers. In 1961 Theodore L. Sourkes, a biochemist at the Department of Psychiatry, McGill University, wrote a review article on the biochemistry of mental illness in which he cited several articles presenting evidence fatal to the adrenochrome theory (Sourkes, 1961). Worst of all, the CMHA, which had supported Hoffer hitherto, funded a series of studies which conclusively demonstrated that nicotinic acid therapy was ineffective (Ban, 1971a, 1971b; Ban and Lehrmann, 1971).

Saskatchewan researchers did not neglect research into the psychological characteristics of LSD itself. When that programme began, almost nothing was known about the appropriate dosage levels and possible side effects of LSD. The psychiatrist Nick Chwelos and the psychologist Duncan Blewett therefore self-administered LSD and recruited some volunteers into their initial programme. As a result of their work they drew up a protocol for LSD's use in psychotherapy. ${ }^{21}$ Chwelos, Blewett and some of their colleagues also made informal use of the drug by ingesting it and then walking through the wards at Weyburn in order, as they believed, to experience and to develop some understanding of the inner world of the schizophrenic. They also carried out some informal research into the properties of LSD as a psychotherapeutic agent, especially in group therapy sessions in which both therapist and 
patients ingested the drug. The only formal programme using LSD as a therapeutic programme was the treatment of alcoholism; for a summary of that work, see Hoffer and Osmond, 1967: 155-68.

In community psychiatry, Saskatchewan researchers carried out an idiosyncratic set of research programmes (some of the work was reviewed by McKerracher, 1969). For example, McKerracher devoted most of his research career to demonstrating, by instituting the required medical procedures and training programmes, that almost all care of the mentally ill could take place during relatively brief stays in psychiatric wards in general hospitals, often under the care of general practitioners or even as part of a medical practice, so that only intractable patients (such as those suffering from senile dementia) would have been assigned to mental hospitals (McCorkell and McKerracher, 1962; McKerracher, Smith, Coburn and McDonald, 1965; Smith and McKerracher, 1967). One can call such a programme a branch of community psychiatry only in the sense that, had it been successful, all care of the mentally ill would have taken place in communities outside mental hospitals. McKerracher's most successful venture was his initiation of two programmes, one for an urban and one for a rural practice, in which general practitioners were assigned beds in the psychiatric ward at the University Hospital, Saskatoon, and, essentially, trained to work as psychiatrists. In particular, they were encouraged to give their psychiatric patients as much care in their offices as possible The programmes greatly reduced the need for in-hospital care and appeared to have been therapeutically successful. Regrettably, they were not used elsewhere in Saskatchewan (or in Canada, so far as I know). Colin M. Smith (b. 1927) was the other leading community psychiatrist in Saskatchewan. ${ }^{22}$ His research work largely consisted of followup studies of those discharged from mental hospitals (e.g., Levey and Smith, 1965; Smith and McKerracher, 1963, 1964/5; Smith, McKerracher and Demay, 1964).

Saskatchewan was also the site of the first extensive programme exploring attitudes towards mental illness. Like so much of the other research in Saskatchewan, the research was action-oriented in that the researchers, Elaine and John Cumming, attempted to change attitudes in order to see if people could be made receptive to the dispersal of institutionalized mental patients into the broader community (Cumming and Cumming, 1957). Although their attempt to induce favourable attitudes to mental illness failed, their ambitious study and their discussions of the reasons why they failed opened the way for others to study the problem.

In the area of general research into the psychology and sociology of mental illness, Osmond gathered together a group of researchers at Weyburn who were largely left to their own devices to work on areas ancillary to psychiatric practice proper. I will deal here only with the work of Robert Sommer and of Teodor Ayllon. Sommer carried out ground-breaking research, both substantively and methodologically. His studies of the role of relative spatial 
configurations in human social interactions laid the foundations for social distance theory, which offers a comprehensive account of the role played by the relative social spacing of participants in face-to-face interactions, both interpersonally and cross-culturally (see especially Sommer, 1959). Methodologically, Sommer showed his fellow social scientists how to carry out research projects, providing useful practical guidance to client groups and how to orient research projects towards practical ends without sacrificing methodological rigour (Sommer, 1999). Overall, his work at Weyburn cannot be fully recaptured from his published work. He devoted his early career to a concerted and broadly-based attempt to improve the lot of those consigned to mental hospitals, both the patients and the staff. For example, he collaborated with Osmond and the architect Kiyo Izumi in planning small mental hospitals designed to avoid what were seen as the iatrogenic characteristics of large institutions such as Weyburn.

Ayllon laid the foundation for his later work on what became known as token economies at Weyburn. ${ }^{23} \mathrm{~A}$ token economy is, in essence, a means for socializing severely psychotic, institutionalized mental patients; Ayllon's token economies represented one of the best-conceived examples of the application of the techniques of behaviour modification. At Weyburn, Ayllon trained nurses to act as socializing agents. He persuaded them to praise desirable behaviour or to associate minor rewards with it and to ignore undesirable behaviour. In general, patients in his programme became relatively tractable and displayed relatively little overt pathology. ${ }^{24}$

\section{An evaluation of the CCF's mental health programmes}

Saskatchewan's mental health programmes were designed to meet the needs of the immediate post-World War II era within a particular ideological framework and set of practices. In part, then, any attempt to assess the success and value of the PSB's programmes must be made within that framework. Furthermore, given the freedom of action accorded to senior PSB psychiatrists, any historian has to take into account their personalities and their interactions with one another. At the same time, one can ask how the PSB's policies can be fitted into some broad ideological and conceptual framework and, above all, one can ask whether or not those policies provided lessons for the future, especially for modes of dealing with the mentally ill beyond the walls of large mental hospitals.

At the outset one has to say that, whatever the defects of the Saskatchewan CCF's psychiatric programmes, they were characterized by a high level of professional competence and by a genuine concern for those suffering from mental illness. Douglas, both as Premier and as a Minister of Public Health, did everything in his power to assist the PSB to develop and operate an effective mental health programme, while his two successors as Ministers of Public Health (Tom J. Bentley and Walter Erb) showed an equally high 
level of dedication. In F. Burns Roth, the government had the services of a superb public servant with an astonishing grasp of the detailed workings of the PSB, combined with a willingness to delegate authority to the psychiatristbureaucrats working under him, thereby helping to maintain the PSB's morale. Chuck Jillings and Stanley Rands, although professionally trained as psychologists, were given control of the day-to-day operations of the PSB's head office and discharged their duties admirably. Many gifted psychiatrists, other than those I have named so far, worked in Saskatchewan.

To the psychiatrists and medical bureaucrats of the 1950s and 1960s, the Saskatchewan government's mental health policies must have seemed successful. A reading of the annual reports of the PSB shows that, in almost every successive year from 1946 to 1964, existing services were progressively expanded, that new services were added, and that services increased their reach, especially by adding travelling clinics in the rural areas ${ }^{25}$ Lawson crisply summarized the PSB's achievements up to $1958 .{ }^{26}$ Those suffering from mental retardation, who had been housed under appallingly bad conditions in the basement of the Saskatchewan Hospital, Weyburn, in 1944 were moved to a separate institution at Moose Jaw. Even though admission rates at Weyburn and North Battleford had increased between 1944 and 1958, by the end of that year the total population in both hospitals had fallen by 900 (and was to fall steeply in the early 1960s). In 1944, discharge rates stood at $62.5 \%$ of admissions, where the corresponding figure for 1957 was $83.9 \%$. Weyburn and North Battleford had been extensively remodelled; new wards had been added, and more therapy was being undertaken. In addition, a wing for mental patients suffering from TB had been added at Weyburn and two wings for ambulatory elderly patients at North Battleford. Staffing programmes had been solved, and (as is evident from earlier sections of this paper) the staff was of generally high quality. The proportion of psychiatrically trained nursing staff at Weyburn and North Battleford was higher than it was anywhere else in Canada; about $90 \%$ of the mental hospital nursing staff were graduates of Saskatchewan's psychiatric nursing programme. The administration of the mental hospitals had been reorganized in order to introduce procedures specifically designed to deal with the mentally ill and to serve the needs of the staff. Above all, treatment in outpatient facilities had greatly increased. With respect to those treated in hospitals, in 1945 the number of patients treated at the one facility available was 275 ; the comparable figure for 1958 was 1053, and in the same year 2715 patients were treated in four full-time and ten part-time or travelling clinics, which also gave consultative services to general practitioners.

Furthermore, Saskatchewan's policies towards those suffering from mental disorders or defects differed radically from those in other Canadian provinces. ${ }^{27}$ In addition, Saskatchewan's treatment of them differed markedly from Alberta's and British Columbia's. In Saskatchewan, the government eventually built a large facility for the education of all patients who could benefit from 
such a programme and who could be placed in sheltered employment, while ensuring that more severe cases were given adequate care. Moreover, in the Department of Psychiatry at the University of Saskatchewan, it created a programme whose staff was trained to recognize early signs of mental deficiency and who trained parents to care for their afflicted children. Alberta and British Columbia, in contrast, used sterilization as one means of dealing with the 'threat' of mental deficiency. Both passed legislation permitting sexual sterilization, Alberta in 1928 and British Columbia in 1933 (both Acts were repealed in 1972). ${ }^{28}$

Towards the end of its period in office, the Saskatchewan CCF government enacted legislation offering comprehensive protection of the rights of those suffering from mental illness. ${ }^{29}$ In particular, the 1961 Mental Health Act contained clauses making voluntary admission possible; the Act proved to be the model, albeit after a considerable delay, for other Canadian provinces. ${ }^{30}$ It was also noteworthy because it was promulgated only after very thorough and wide-reaching consultations with PSB psychiatrists and a thorough review by the office of the Attorney-General.

Even so, it cannot be said that the Saskatchewan CCF government's mental health programmes of the 1950s and 1960s were successful in every respect. At the simplest level, it is surprising that, despite the large budget allocated to mental health, the conditions at the province's two large psychiatric hospitals remained so bad until well into the 1950 s. Indeed, levels of sanitation at Weyburn were so low that it seems that only the patients' immune systems prevented a severe outbreak of infectious disease.

More comprehensively, there is considerable evidence showing that by 1968 Saskatchewan's mental health situation was in a state of crisis (see, e.g., Smith, 1971). ${ }^{31}$

The senior PSB psychiatrists played out complex roles within the system. Saskatchewan's allure attracted several strong-minded men with strong opinions about the nature of mental illness and the means for dealing with it (especially McKerracher, Hoffer, Osmond and Lawson). Because the system was so open and because it placed such trust in the capacities of its senior staff, each tended to develop his own programmes with comparatively little contact or consultation, resulting in serious inefficiencies. Those problems were exacerbated because there was no strong central bureaucracy that could have held the balance between what were in effect semi-independent fiefdoms. Matters were made worse because both McKerracher and Hoffer directly appealed to Douglas whenever they encountered a serious problem.

McKerracher, for example, once he became head of the Department of Psychiatry, actively pursued his programme training general practitioners to act as psychiatrists. The programme did not become integrated into the PSB's programmes partly because McKerracher was fully occupied with the life and internal politics of the College of Medicine and of the University Hospital and partly because Douglas appealed to McKerracher for help in 
his conflict with Lawson over the Saskatchewan Plan. McKerracher, believing that purpose-built mental hospitals (the centrepiece of the Plan) were unnecessary, recommended the virtues of his own programme to Douglas, thereby infuriating Lawson and ending their relationship. ${ }^{32}$

Lawson, despite his geniality and his intense loyalty to his senior staff, was by no means without faults. For one thing, in my opinion (though not necessarily in the opinion of some of my informants) he pursued his version of community psychiatry implacably and without taking any account of its potentially ruinous effect on the provincial budget. For another, he showed serious failures as an administrator. Because of his loyalty to his senior staff, he was blind both to their deficiencies and to the impact of those deficiencies on the morale and effectiveness of the non-medical staff. ${ }^{33}$

Hoffer was pre-eminent among those psychiatrists who enhanced Saskatchewan's psychiatric reputation. His unusual combination of ideological fervour, biochemical knowledge, grasp of scientific practice, and psychiatric expertise ensured that, for a few years at least, the Hoffer-Osmond adrenochrome theory of the origin of schizophrenia occupied a prominent place on the neuropharmacological stage. However, Hoffer pursued his programmes with the most ruthless disregard for the opinions of others. He refused to address concerns expressed about his methods or to explore versions of the transmethlyation hypothesis alternative to his. Above all, he consistently attempted to discount the considerable body of evidence demonstrating that nicotinic acid therapy was ineffective. Despite all the evidence, he believed that schizophrenia could be cured, and he retreated into a world of his own, with an idiosyncratic diagnostic system and therapeutic method. As a result, he alienated himself not just from Saskatchewan's medical fraternity but even from his fellow PSB psychiatrists.

Largely as a result of the role played within it by Lawson and Hoffer, the CMHA (Sask) - which potentially should have been a strong advocate for the rights and welfare of the mentally ill - was drawn into the conflict over the Saskatchewan Plan and almost entirely devoted itself to the promotion of a particular version of the Plan. Furthermore, CMHA (Sask) had an unduly close relationship with the PSB: for some years CMHA (Sask)'s Executive Secretary was Hoffer's brother-in-law, and also one of Hoffer's sisters, Elsie Kahan, played a prominent role in CMHA and as an advocate for her brother's research and therapeutic programmes. Moreover, Hoffer used the CMHA (Sask) to promote his biologically-based therapy for schizophrenia. Those links gave the government the impression that it was not receiving dispassionate advice from its own employees, while the obduracy of the CMHA infuriated Douglas and his cabinet. They therefore refused to implement the Saskatchewan Plan fully and CMHA (Sask) withered away.

In order to become and remain fully effective, the Saskatchewan mental health programme had to retain the services not just of the psychiatrists needed to staff it but of psychiatrists with particular interests and types of 
expertise. Those psychiatrists who joined the PSB in its early years did so only because it offered them the opportunity to engage in innovative practices and in research. ${ }^{34}$ When the practices that were at first innovative had become routine, the programme's capacity for attracting new staff declined. At the same time, the psychiatrists working in Saskatchewan were lured away, either to other Canadian provinces or to the USA. ${ }^{35} \mathrm{Had}$ Saskatchewan developed a comprehensive programme of psychiatric research centred on a research institute, it might have retained the services of the types of psychiatrists it needed.

Hoffer and the CMHA (Sask) did propose the creation of a large research institute, ${ }^{36}$ but for various reasons the idea never came to fruition. One could probably say that fiscal considerations alone nullified the proposal. In 1964 the CCF lost power to a Liberal government who demanded careful accountability from all the government's existing and proposed programmes. Such accountability, it would appear, would not have been forthcoming in the case of a psychiatric research unit because there is no evidence that Lawson and his staff suggested what types of research the institute might have undertaken. Instead, the archival evidence suggests that Lawson delegated the planning of the institute's proposed activities to Hoffer. ${ }^{37}$ This meant that the research would have been devoted to a narrowly conceived biochemical programme, when the need was for a broad-based programme in community psychiatry. Furthermore, it was proposed that the institute should come under the ultimate supervision of the University of Saskatchewan's College of Medicine. The medical faculty's hostility to Hoffer ensured that it never became a reality.

The personal histories of the senior PSB staff and the policies they promoted can be fully understood only if they are placed within some reasonably broad interpretive framework. Wolfensberger (1972) provides us with one starting point by proposing several models of deviancy which he defined very broadly; he wrote: 'A person can be said to be deviant if he is perceived as being significantly different from others in some respect that is considered of relative importance, and if this difference is negatively valued.' (Wolfensberger, 1972: 12). Given their degree of professional commitment, their intelligence and their status within psychiatry, the PSB psychiatrists had implicit models of deviancy, which, one could argue, helped to shape their practice. Thus, both McKerracher and Lawson regarded the mentally ill as objects of pity. For example, it is very clear from his annual reports that Lawson wanted those suffering from mental illness to be treated in exactly the same way as those suffering from physical illnesses and wanted their physical living conditions to match of those in society at large. Moreover, both were immune to what Wolfensberger (1972: 20) called 'the sour charity approach' (which would have meant incarcerating the chronically mentally ill in institutions stripped of all pleasant amenities). One could also, perhaps, characterize the conflict between Douglas and Lawson over the implementation of the Saskatchewan 
Plan within the framework of that model, given that attitudes from the eugenics era appeared to linger within Douglas's psyche.

As they were trained in medicine, all the PSB psychiatrists saw the mentally ill from the standpoint of another of Wolfensberger's models, the deviant as a diseased organism. Wolfensberger (1972: 20-1) characterized two forms of the diseased organism model, one in which the mentally ill are accorded roughly the same treatment as sick animals and another in which they are accorded a fully human status. Once again, the latter variant drove the practice of McKerracher, Lawson and many of the PSB psychiatrists, psychologists, psychiatric nurses and psychiatric social workers.

One can follow the implications of Wolfensberger's diseased organism model further by asking whether those treating the mentally ill or those responsible for providing funds for their welfare placed client populations within the area of clinical medicine or within the public health system. ${ }^{38}$ Given the public health system's ancestry in the provision of minimal care to, or even the segregation of, those considered to be deviant, a public health model carried at least the connotations of some sort of second-order or residual care. Moreover, public health systems tend to deliver fairly poor levels of service in dispersed and poorly co-ordinated treatment centres. Even McKerracher, with his insistence that most psychiatric problems could be treated initially in general hospitals, demanded high levels of care.

However, the fact that the work of the PSB was infused with a set of worthy principles is only significant if those principles manifested themselves in potentially effective practices and could have yielded tangible benefits for clients. Beyond that, one should also ask whether the system was sufficiently robust to carry itself into the de-institutionalized era of contemporary psychiatry and whether the PSB's work carried any lessons for the future.

The answer has to be that, at least in terms of policies, the PSB devised a system that was robust and potentially effective. Long before the major tranquillizers were available, McKerracher had undertaken three policy initiatives that laid the framework for the practices of the de-institutionalized era: he had set up a programme for training psychiatric nurses within Saskatchewan; initially with the assistance of the CMHA (Sask) he had begun to create a network of approved homes; and, partly with the assistance of the CMHA and partly by fostering research, he had attempted to prepare Saskatchewan's people to receive the mentally ill into their midst. So, when Lafave and Grunberg began to discharge large numbers of mental patients from Weyburn, they did not go into a social vacuum.

Saskatchewan psychiatric practice in the early 1960s, then, contrasted starkly with that of other Canadian provinces and the rest of the world. ${ }^{39}$ Eventually, other Canadian provinces adopted Saskatchewan's policies. Goodwin noted that, in Canada overall from 1970 to 1980 , only $0.11 \%$ of Ministry of Health funds were spent on community mental health programmes; by the 
late 1980 s the proportion lay in the range $10-30 \%$ and only in Saskatchewan was it greater than 50\% (Goodwin, 1997: 14, 101-2).

In part, that psychiatric practice formed part of an area in which Saskatchewan excelled, namely, the micro-management of governmentdelivered services. ${ }^{40}$ Based on a trial study initiated in 1962, discussions with the appropriate trade unions and a later review by the Saskatchewan Public Service Commission, two new categories of psychiatric nurse, Community Psychiatric Nurses I and II, were created and training programmes initiated. As their titles suggest, these nurses were deployed in the community and not in mental institutions. A former director of psychiatric nursing programmes in Saskatchewan, Malcolm ('Max') Schreder (1985: 6) ${ }^{41}$ commented:

Psychiatric nurses, through their training, have educational preparation in the dynamics of human behaviour, a broad understanding of psychiatric and emotional disorders and consequently the manifestation of symptoms, a keen sense of understanding of interactions in the emotional milieu, and the manipulation of the environment to promote healthy interaction along with a sound basic knowledge of psychiatric treatment including chemotherapy. In addition, the psychiatric nurses in this province tend to be the most stable members of the community psychiatric team since they remain in the position for long periods of time. ... The program in community psychiatric nursing therefore provides for continuity of care in the community. Psychiatric nurses provide understanding, support, and guidance to the patient and key figures in his/her environment, counseling in daily living activities and, above all, in being a helping person in whom the patients can build their trust. The role of the psychiatric nurse in the community is a crucial one. They are the persons on the spot making regular home visits and fulfilling the 'traditional helping role.'

The Saskatchewan CCF government demonstrated that it was possible to devise and enact policies for the care and treatment of the mentally ill in community settings. A close and extensive reading the archival record, combined with interviews with the surviving members of those who worked in the PSB during the period I have reviewed, should allow historians to discover why the programmes were viable and what lessons they bear for the future. Regrettably, it may well be the case that Saskatchewan's policies cannot be replicated. The CCF cabinet and Saskatchewan's senior bureaucrats provided what may well have been a unique working environment in which a great deal of trust was placed in government employees and in which many professionals enjoyed considerable freedom of action. At the same time, the government did its best to maintain good working relationships with its unionized personnel. Even so, if contemporary medical bureaucrats could be persuaded to acquaint themselves with what was achieved in Saskatchewan they might be inspired to attempt to replicate it.

Finally, I hope that this paper provides a memorial to the achievements of those who worked for the PSB in its days of glory. I have met or corresponded 
with many of them, and all were proud of their achievements - and so they should be.

\section{Acknowledgements}

The research for this article was partially assisted by a grant from the Department of Psychology, University of Saskatchewan. The author would like to thank the journal's two referees for their very helpful comments on the first draft of this article.

\section{Notes}

1. Douglas's virtues were not as apparent to his contemporaries as they are today, nor did the policies of his government induce universal consent. When the CCF ran for re-election under its new name, the New Democratic Party (NDP), in 1964 it was defeated and did not regain power until 1971. Even worse, Douglas, who had been elected leader of the Federal NDP, was badly defeated in a Regina constituency in the Federal election of 1962 (he was eventually elected to parliament in a constituency in British Columbia).

2. Hall's document is a long and detailed history of the introduction of medicare in Saskatchewan, written for the province's Department of Health in 1978-79. I could not find a copy in the Saskatchewan Provincial Archives or the Archives of the University of Saskatchewan, so I am most grateful to Dr Terry Russell and Mrs Sharon Russell for lending me their copy.

3. Douglas expounded a particularly robust form of eugenics, typical of the time. However, like other left-wing eugenicists, such as J. B. S. Haldane, he ceased to advocate sterilization policies once he had visited Nazi Germany and heard of its draconian sterilization policies and its use of euthanasia. On the other hand, despite Douglas's sincere Christianity, it would appear that he did have a lingering tendency to deny full humanity to certain groups (a premise underlying policies such as the sterilization of the 'mentally unfit'). One of his biographers, Walter Stewart (2003), detected lingering racism in Douglas's attitudes; for example, he refused to condemn the internment and seizure of the property of Japanese-born Canadians during World War II.

4. See Douglas's correspondence on this matter: Douglas Papers, R-33.5 III. 134. Saskatchewan Archives Board, Regina, Saskatchewan, Canada.

5. Hall (1979, III) and Houston (2002) give accounts of the pre-medicare era in Saskatchewan. The political responses in Western North America to the Great Depression and to the years of drought which, fortuitously, accompanied it were complex and varied. There is an intimate connection between agrarian socialism and highly conservative movements such as social credit which, although it eschewed any government regulation of business or industry, urged capitalists to share some of their profits with the general populace (Finlay and Sprague, 1997: 380). Social credit governments were elected in Alberta in 1935 and in 1952 in British Columbia.

6. Government of Saskatchewan, An Act Respecting Mentally Defective, Mentally Ill and Other Persons (cited as: The Mental Hygiene Act), 1950.

7. For a history of the University of Saskatchewan, see Hayden, 1983.

8. These staffing problems are discussed at length by Dickinson, 1989: 82-132.

9. For an obituary of McKerracher, see Canadian Psychiatric Association fournal, 15: 246 (1970). I derived my opinions of McKerracher's character from interviews with Dr Frank Coburn, Saskatoon (Oct. 2000) and with Dr Ian McDonald, The Royal University Hospital, Saskatoon (3 Mar. 2003).

10. Typically, the Saskatchewan programme was more comprehensively organized and better integrated into the staffing framework of the Department of Public Health than it was 
in other provinces. As an example, see the account of psychiatric nursing as practised in one of Manitoba's mental hospitals given by Dooley, 2004.

11. For a biography of Hincks, see Roland, 1990.

12. Lawson commented as follows on the conditions at Saskatchewan's two mental hospitals: 'The Weyburn hospital stunk [sic] like something out of this world ... the whole basement area was a shambles, naked people all over the place lying around, incontinent. There was a lot of seclusion in use, and mechanical restraints. The North Battleford hospital did not use mechanical restraints, and the hospital was pretty good except for one area where it was the custom to send the least satisfactory patients and the least satisfactory staff. This was a ward of 175 patients who didn't wear clothes, who slept on straw ticks on the floor, and who were roused at $2 \mathrm{am}$ to go to the toilet and then hosed down with cold showers to clean them off ... The patients used to wear burlap dresses, but we abolished these and dressed them a little better.' (quoted in Hall, 1979, VI: 14)

13. For a history of the Saskatchewan government's flirtation with the idea of a third mental hospital, see Hall, 1979, VI: $11 \mathrm{ff}$.

14. 'The Saskatchewan Hospital Survey' (March, 1954; unpublished). Douglas Papers, R-33.5 III. 127, File 3. Saskatchewan Archives Board.

15. I read the copy of Lawson's proposal appended to a memorandum from Tom J. Bentley, the Minister of Public Health, to Douglas on 7 June 1955. Douglas Papers, R-33.5 III. 127, Saskatchewan Archives Board.

16. For a discussion of that episode and some of its aftermaths, see Dickinson, 1989: $146-71$.

17. For a comprehensive history of the background to that project, see Kahan, 1965.

18. An incomplete 1962 bibliography lists about 240 items concerning research in schizophrenia alone; fournal of Neuropsychiatry, 2, 371-4 (1962).

19. Hoffer told me that his research funding had totalled about $\$ 500,000$ (roughly two million dollars in current value); Abram Hoffer, e-mail to the author, 13 Dec., 2004.

20. From a scientific viewpoint, Hoffer's obduracy has excluded him from his rightful place in the history of neuroscience. His commitment to his position, however, is one of the forces controlling his very successful career as a therapist. Certainly, few psychiatrists share his level of concern for and depth of understanding of those who suffer from psychotic disorders.

21. Duncan Blewett and Nick Chwelos, 'Handbook for the Therapeutic Use of Lysergic Acid Diethylamide 25: Individual and Group Procedures' (unpublished); the document is not dated. However, Dr Blewett told me that he produced the protocol shortly after he arrived in Weyburn in 1958 (interview with the author, Gabriola Island, British Columbia, July 2003). Hoffer told me that Timothy Leary obtained a copy of Blewett and Chwelos's document and used it as the basis for his own work with LSD (Hoffer, interview with the author, Victoria, British Columbia, 28 July 2000). I would like to thank Dr Terry Russell for lending me a copy of the document.

22. Smith succeeded Dr Frederic Grunberg as the Director of the PSB.

23. For an account of token economies, see Ayllon and Azrin, 1968. For a critical review of those programmes, see Mills, 1998: 165-78.

24. For Ayllon's work at Weyburn, see: Ayllon and Haughton, 1962; Ayllon and Michael, 1959.

25. For the period reviewed in the present paper, see Reports of the Department of Public Health, published annually by the Government of Saskatchewan (1944-45 et seq.); copies are lodged in the Saskatchewan Archives Board.

26. Lawson was responding to a request from Douglas, who had been asked by Gordon H. Dowding, an opposition Member of the Legislative Assembly of British Columbia, 
for information about services offered in Saskatchewan for those suffering from mental illness; Douglas Papers, R-33.5 III. 127, File 14-8, Saskatchewan Archives Board.

27. For conditions in Ontario, Alberta and Nova Scotia, respectively, see: Simmons, 1990; LaJeunesse, 2002; Fingard and Rutherford, 2005.

28. For the provisions for sexual sterilization in Alberta, see the province's The Sexual Sterilization Act, which was enacted in 1928. For similar provisions in British Columbia, see that province's Sexual Sterilization Act, enacted in 1933. For a discussion of eugenics in Canada, see McLaren, 1990.

29. Government of Saskatchewan, An Act respecting Mentally Disordered Persons (cited as The Mental Health Act), 1961.

30. In Canada as a whole, it was only in the 1970 s that a majority of mental patients were voluntarily admitted (Goodwin, 1997: 92).

31. For a thorough review of the CCF government's psychiatric programmes, see Shervert H. Frazier and Alex D. Pokorny (1968) 'Report of a Consultation to the Minister of Public Health on the Psychiatric Services of Saskatchewan' (unpublished). Gordon Grant Papers, Collection R-45, file 90, Saskatchewan Archives Board.

32. See the long letter which McKerracher wrote to Douglas on 29 March 1957 (Douglas Papers, R-33.5, File 14-26). Dickinson (1989: 157-8) quotes a passage from this letter. Frank Coburn told me of the breach between McKerracher and Lawson (Coburn, interview with the author, Saskatoon, October 2000).

33. One example of Lawson's failure to deal with staffing and morale problems can be found in the Douglas Papers (R-33.1 XIV. 554, four folders. Saskatchewan Archives Board). For some years, the non-medical staff at the Saskatchewan Hospital, North Battleford, had been in conflict with the medical staff. The Government came to know of those problems, which reached a crisis in 1958, from the local Member of the Legislative Assembly and not through the PSB. Douglas expressed considerable displeasure with Lawson's failure to discharge his administrative duties.

34. Burns Roth commented: 'We must be perfectly frank and recognize that, given a choice, no psychiatrist would come to Weyburn, North Battleford or any other smaller centre in this province because of the weather, the social and cultural amenities or the living conditions.' (Memorandum to Erb, 6 July 1961, Douglas Papers, R-33.1 XIV. 554, Folder 4, Saskatchewan Archives Board.)

35. Burns Roth further commented: 'The facts are that other areas are rapidly catching up and the balance of attraction as between professional stimulation on the one hand and the social amenities and improved salaries on the other is going against us.' (Ibid., see Note 34)

36. Hoffer told me that he asked Douglas and the then Federal Minister of Health, J. Waldo Monteith, for funds for the proposed institute. Both, according to him, agreed (Hoffer, interview with the author, Victoria, 28 July 2000).

37. That evidence is to be found in the Papers and Correspondence of the Department of Psychiatry, University of Saskatchewan (Archives of the University of Saskatchewan, Saskatoon) and in the Walter Erb Papers, GR 91. File 013Y1, Saskatchewan Archives Board.

38. For a review of this issue, see Burnham, 2006.

39. See, especially, Goodwin, 1997: ch. 6. For an especially searing depiction of deinstitutionalization, see Burnham, 2002.

40. For an overall account of the Saskatchewan civil service in the CCF era, see Johnson, 2004.

41. I am most grateful to Art Gondziola, who sent me a copy of Schreder's paper. 


\section{References}

Ayllon, T. and Azrin, N. H. (1968) The Token Economy: A Motivational System for Therapy and Rehabilitation (New York: Appleton-Century-Crofts).

Ayllon, T. and Haughton, E. (1962) Control of the behavior of schizophrenic patients by food. Fournal of the Experimental Analysis of Behavior, 5, 343-52.

Ayllon, T. and Michael, J. (1959) The psychiatric nurse as a behavioral engineer. fournal of the Experimental Analysis of Behavior, 2, 323-34.

Ban, T. A. (1971a) Nicotinic Acid in the Treatment of Schizophrenia: Introduction (Toronto: The Canadian Mental Health Association).

Ban, T. A. (1971b) Nicotinic Acid in the Treatment of Schizophrenia: Complementary Report A (Toronto: The Canadian Mental Health Association).

Ban, T. A. and Lehrmann, H. E. (1971) Nicotinic Acid in the Treatment of Schizophrenia: Progress Report (Toronto: The Canadian Mental Health Association).

Burnham, J. C. (2002) Paper presented at a conference of Division 25 of the American Psychological Association [June].

Burnham, J. C. (2006) A clinical alternative to the public health approach to mental illness: a forgotten social experiment. Perspectives in Biology and Medicine, 49, 220-37.

Cumming, E. and Cumming, J. (1957) Closed Ranks: An Experiment in Mental Health Education (Cambridge, MA: Harvard University Press).

Dickinson, H. D. (1989) The Two Psychiatries: The Transformation of Psychiatric Work in Saskatchewan 1905-1984 (Regina, Sask.: Canadian Plains Research Center).

Dooley, C. (2004) "They gave their care, but we gave loving care": defining and defending boundaries of skill and craft in the nursing service of a Manitoba mental hospital during the Great Depression. Canadian Bulletin of Medical History, 21, 229-51.

Final Report of the Advisory Committee on Medical Care to the Government of Saskatchewan (Regina, Sask.: Queen's Printer, 1962).

Fingard, J. and Rutherford, J. (2005) The politics of mental health care in Nova Scotia: the case of the Halifax County Hospital, 1940-1976. Acadiensis, 35, 24-49.

Finlay, J. L. and Sprague, D. N. (1997) The Structure of Canadian History, 5th edn (Scarborough, ON: Prentice-Hall).

Goodwin, S. (1997) Comparative Mental Health Policy: From Institutional to Community Care (London: Sage).

Government of Saskatchewan (1944-45 et seq.) Reports of the Department of Public Health, "Psychiatric Services Branch" (Regina, Sask.: Queens Printer).

Griffin, J. D. (1989) In Search of Sanity: A Chronicle of the Canadian Mental Health Association, 1918-1988 (London, ON: Third Eye Publications).

Hall, R. K. (1979) The co-operative vision: the building of the Saskatchewan health system. Unpublished MS (see Note 2).

Hayden, M. (1983) Seeking a Balance: University of Saskatchewan, 1907-1982 (Vancouver: University of British Columbia Press).

Healy, D. (2002) The Creation of Psychopharmacology (Cambridge, MA: Harvard University Press).

Hoffer, A. and Osmond, H. F. (1959) The adrenochrome model of schizophrenia. fournal of Nervous and Mental Diseases, 128, 18-38.

Hoffer, A. and Osmond, H. F. (1960) The Chemical Basis of Clinical Psychiatry (Springfield, IL: Thomas).

Hoffer, A. and Osmond, H. F. (1967) The Hallucinogens (New York: Academic Press).

Hoffer, A., Osmond, H. F. and Smythies, J. (1954) Schizophrenia: a new approach. II. Results of a year's research. Fournal of Mental Science, 100, 29-45. 
Houston, C. S. (2002) Steps on the Road to Medicare (Kingston, ON: McGill-Queens University Press).

Johnson, A. W. (2004) Dream No Little Dreams: A Biography of the Douglas Government of Saskatchewan, 1944-1961 (Toronto: University of Toronto Press).

Kahan, F. (1965) Brains and Bricks: The History of the Yorkton Psychiatric Center (Regina, Sask.: White Cross Publications).

LaJeunesse, R. A. (2002) Political Asylums (Edmonton, AB, Canada: The Muttart Foundation).

Lawson, F. S. (1957) The Saskatchewan Plan. Mental Hospitals, 8, 27-31.

Lawson, F. S. (1958) Mental hospitals: their size and function. Canadian fournal of Public Health, 49, 186-95.

Lawson, F. S. (1967) The Saskatchewan Plan. The Canadian Nurse, 63, 27-9.

Lawson, F. S. and Izumi, K. (1965) The Yorkton Psychiatric Centre. Mental Hospitals, $16,85-9$.

Levey, A. B. and Smith, C. M. (1965) Follow-up and the measurement of change in psychiatric patients. Acta Psychiatrica Scandinavica, 41, 236-50.

Lipset, S. M. (1968) Agrarian Socialism: The Cooperative Commonwealth Federation in Saskatchewan. A Study in Political Sociology, rev. edn (Berkeley: University of California Press).

McCorkell, W. J. and McKerracher, D. G. (1962) The family doctor and the psychiatric ward. Mental Hospitals, 11, 300-2.

McKerracher, D. G. (1969) Research in Saskatchewan. In R. H. Williams and L. D. Ozarin (eds), Community Mental Health: An International Perspective (San Francisco: Josey-Boss), 370-81.

McKerracher, D. G., Smith, C. M., Coburn, F. E. and McDonald, I. M. (1965) General practice psychiatry: two Canadian experiments. The Lancet, (13 Nov.), 1005-7.

McLaren, A. (1990) Our Own Master Race: Eugenics in Canada, 1885-1945 (Toronto: Oxford University Press).

McLeod, T. H. and McLeod, I. (1987) Tommy Douglas: The Road to ferusalem (Edmonton, AB, Canada: Hurtig Publishers).

McMillan, J. D. (1957) Community mental hospital. The Canadian Hospital, 34, 40-6.

Mills, J. A. (1998) Control: A History of Behavioral Psychology (New York: New York University Press).

Osmond, H. F. and Hoffer, A. (1961/2) Pro domo sua: A brief account of the Saskatchewan research in psychiatry. Fournal of Neuropsychiatry, 2, 287-91.

Osmond, H. F. and Hoffer, A. (1966) A comprehensive theory of schizophrenia. International Fournal of Neuropsychiatry, 2, 302-9.

Osmond, H. F. and Smythies, J. (1952) Schizophrenia: a new approach. Fournal of Mental Science, 98, 309-15.

Rands, S. (1960) Community psychiatric services in a rural area. Canadian fournal of Public Health, 51, 404-10.

Roland, C. G. (1990) Clarence Hicks: Mental Health Crusader (Toronto: Dundurn Press).

Schreder, M. (1985) Psychiatric nursing in the community. Paper presented to a conference of psychiatric nurses, Ponoka, Alberta, Canada in 1972, and later revised.

Shackleton, D. F. (1975) Tommy Douglas (Toronto: McClelland and Stewart).

Simmons, H. (1990) Unbalanced: Mental Health Policies in Ontario, 1930-1989 (Toronto: Wall \& Thompson).

Smith, C. M. (1971) Crisis and aftermath: community psychiatry in Saskatchewan, 1963-69. Canadian Psychiatric Association fournal, 16, 65-76. 
Smith, C. M. and McKerracher, D. G. (1963) Geriatric aspects of a psychiatric home care program. Fournal of the American Geriatric Society, 40, 339-45.

Smith, C. M. and McKerracher, D. G. (1964/5) The comprehensive psychiatric unit in a general hospital. American fournal of Psychiatry, 121, 52-7.

Smith, C. M. and McKerracher, D. G. (1967) The family doctor in a programme of comprehensive psychiatric care. In H. L. Freeman and J. Farndale (eds), New Aspects of the Mental Health Sciences (Oxford: Pergamon Press), 237-45.

Smith, C. M., McKerracher, D. G. and Demay, M. (1964) A follow-up study of comparable mental and general hospital patients. Canadian Psychiatric Association fournal, 9, 154-73.

Sommer, R. (1959) Studies in personal space. Sociometry, 22, 247-60.

Sommer, R. (1999) Action research: from mental hospital reform in Saskatchewan to community building in California. Canadian Psychology, 40, 47-55.

Sourkes, T. L. (1961) The biochemistry of mental disease. Canadian Medical Association fournal, 85, 487-90.

Stewart, W. (2003) The Life and Political Times of Tommy Douglas (Toronto, ON: McArthur \& Co.).

Wolfensberger, W. (1972) Normalization: The Principle of Normalization in Human Services (Toronto: Leonard Crainford, for the National Institute of Mental Retardation). 